\title{
ANALISIS KANDUNGAN VITAMIN A PADA DAUN PAKU-PAKU (Diplazium escelentum (Retz.)Sw.) BERDASARKAN PROSES PEMASAKAN
}

\author{
Yuliana Souhaly ${ }^{1)}$, M. Nur. matdoan ${ }^{2)}$, S.I.A.Salmanu ${ }^{2)}$ \\ 1)Alumni Pendidikan Biologi \\ 2)Dosen Pendidikan Biologi
}

E-mail: Souhalyulen28@gmail.com

\begin{abstract}
Background: The nails are plants that are often consumed by the community because they are effective in curing various diseases such as cough, asthma, fever, headache, diarrhea, and dysentery. Different cooking processes can affect the nutritional content of a food ingredient, one of which is vitamin A.

Method: This type of research is comparative, namely to compare the content of vitamin A found in ferns (Diplazium esculentum (Retz) Sw.) Based on the cooking process, namely boiling, steaming and stirring. Location of analysis of vitamin A content in the Basic Chemistry laboratory of the Faculty of Mathematics and Natural Sciences, Pattimura University. The subjects of the study were $4 \mathrm{~g}$ of ferns extract, each of which was carried out based on the cooking process, namely stir-fry, boiled and steamed.

Results: There is an effect of the cooking process on the content of vitamin A on ferns. The highest vitamin A content is found in the type of stir-fry cooking which is as much as $0,0594 \%$, the type of steamed cooking is $0,0442 \%$ and the type of boiled cooking is $0,0243 \%$. Sauteed vegetables have relatively low water content than those boiled or steamed.

Conclusion: The highest content of vitamin A in vegetable ferns (Diplazium escelentum (Retz.) Sw.) Was found in the cooking process of the type of stirring with a vitamin A content of 0.0594 with a duration of 10 minutes.
\end{abstract}

Keywords: Vitamin A, Ferns (diplazium escelentum (Retz.) Sw.) cooking process.

\begin{abstract}
Abstrak
Latar Belakang: Paku-paku merupakan tumbuhan yang sering dikonsumsi masyarakat karena berkhasiat menyembuhkan berbagai penyakit seperti batuk, asma, demam, sakit kepala, diare, dan anti disentri. Proses pemasakan yang berbeda dapat mempengaruhi kandungan gizi didalam suatu bahan makanan, salah satunya vitamin $A$.

Metode: Jenis penelitian ini adalah jenis komparatif yaitu untuk membandingkan kandungan vitamin A yang terdapat pada daun paku-paku / pakis (Diplazium esculentum (Retz) Sw.) berdasarkan proses pemasakan, yaitu perebusan, pengukusan dan penumisan. Lokasi analisis kandungan vitamin A Di laboratorium Kimia Dasar FMIPA Universitas Pattimura. Subjek penelitian adalah ekstrak daun pakupaku masing-masing $4 \mathrm{~g}$ yang dilakukan berdasarkan proses pemasakan yaitu tumis, rebus dan kukus.

Hasil: Terdapat pengaruh proses pemasakan terhadap kandungan vitamin A pada daun paku-paku. Kandungan vitamin A yang tertinggi terdapat pada jenis pemasakan tumis yaitu sebanyak $0,0594 \%$, jenis pemasakan kukus sebanyak $0,0442 \%$ dan jenis pemasakan rebus sebesar $0,0243 \%$. Sayuran yang ditumis mempunyai kadar air relatif rendah daripada yang direbus atau dikukus.

Kesimpulan: Kandungan vitamin A pada sayur paku-paku (Diplazium escelentum (Retz.) Sw.)) tertinggi terdapat pada proses pemasakan jenis penumisan dengan kandungan vitamin A sebesar 0,0594 dengan lama waktu 10 menit.
\end{abstract}

Kata Kunci: Vitamin A, daun paku-paku (Diplazium escelentum (Retz.) Sw.), proses pemasakan. 


\section{PENDAHULUAN}

Diplazium esculentum (Retz.) Swartz atau pakis sayur merupakan salah satu tumbuhan paku yang sering dikonsumsi masyarakat karena dianggap memiliki khasiat menyembuhkan berbagai penyakit seperti batuk, asma, demam, sakit kepala, diare, dan antidysentri. Menurut Setyowati (2005), hasil studi etnobotani suku dayak memanfaatkan tanaman ini sebagai obat kencing bernanah atau kencing berdarah. Bagian batang muda Diplazium esculentum juga dimanfaatkan oleh masyarakat Olen Setulang, Malinau Kalimantan Timur sebagai obat penurun panas pada anakanak (Karmilasanti dan Supartini, 2011), Masyarakat Manukwari, Papua Barat juga menggunakan bagian batang mudanya untuk mengobati sakit kepala (Lense, 2012). Ental muda Diplazium esculentum dikonsumsi masyarakat digunakan sebagai tonik untuk kesehatan. Ental merupakan bagian yang terdiri dari tangkai dan helaian daun tumbuhan paku (Fleming, 2009).

Berdasarkan morfologinya, tanaman paku memiliki akar adventif sejumlah akar ditemukan dekat dengan dasar caudis, berfungsi untuk kestabilan. Rhizom biasanya menjalar bercabang baik pada tipe iregular/secara dikotomi. Rhizoid tumbuhan paku sudah berkembang ke arah akar untuk kepentingan hidupnya. Rambutrambut akar akan menyerap air dan garam mineral terlarut, Batang Pteridophyta bercabang-cabang menggarpu (dikotom) atau jika membentuk cabang-cabang ke samping, cabang-cabang baru itu tidak pernah keluar dari ketiak daun. Pada batang Pteridophyta terdapat banyak daun, yang dapat tumbuh terus sampai lama (Tjitrosoepomo, 1991),

Daun tumbuhan paku ada yang berdaun tunggal dan sebagian berdaun majemuk. Daun mejemuk terdiri atas tangkai daun dan helaian daun. Helaian tumbuhan paku secara keseluruhan disebut ental. Berdasarkan fungsinya yaitu tropofil dan sporofil (Tjitrosoepomo, 1983 ).

Vitamin A banyak terkandung dalam sayur-sayuran terutama pada bayam, sawi, dan masih banyak lagi sayur-sayuran yang mengandung vitamin $A$ termasuk daun paku-paku/ pakis

Metabolisme Vitamin A, pencernaan
dan absorpsi karoten dan retinoid

membutuhkan empedu dan enzim pankreas seperti halnya lemak. Vitamin A yang di dalam makanan sebagian besar terdapat dalam bentuk ester retinil, bersama karotenoid bercampur dengan lipida lain di dalam lambung. Di dalam sel-sel mukosa usus halus, ester retinil dihidrolisis oleh enzim-enzim pankreas esterase menjadi retinol yang lebih efisien diabsorpsi dari pada ester retinil. Sebagian dari karotenoid, terutama beta-karoten di dalam sitoplasma sel mukosa usus halus dipecah menjadi retinol. Retinol di dalam mukosa usus halus bereaksi dengan asam lemak dan membentuk ester dan dengan bantuan cairan empedu menyeberangi sel-sel vili dinding usus halus untuk kemudian diangkut oleh kilomikron melalui sistem limfe ke dalam aliran darah menuju hati. Dengan konsumsi lemak yang cukup, sekitar $80-90 \%$ ester retinil dan hanya $40-$ $60 \%$ karotenoid yang diabsorpsi. (Azrimaidaliza, 2007).

\section{MATERI DAN METODE}

Jenis penelitian ini adalah jenis komparatif yaitu untuk membandingkan kandungan vitamin A yang terdapat pada daun paku-paku / pakis (Diplazium esculentum (Retz) Sw.) berdasarkan proses pemasakan, yaitu perebusan, pengukusan dan penumisan.

Tempat pengambilan sampel pada Desa Talaga Pange Kecamatan Teluk Ambon Kota Ambon.

Lokasi analisis kandungan vitamin A Di laboratorium Kimia Dasar FMIPA Universitas Pattimura. Pelaksanaan penelitian ini di mulai dari tanggal 24 maret sampai dengan 3 April 2017.

Subjek pada penelitian ini adalah ekstrak daun paku-paku masing-masing $4 \mathrm{~g}$ yang dilakukan berdasarkan proses pemasakan yaitu tumis, rebus dan kukus.

Alat-alat yang dipakai dalam penelitian ini adalah Spektrofotometer, Corong pisah, Corong prucher, Kolom kromatografi, Erlenmeyer , Timbangan analitik , Kertas saring, Blender, Stopwath, Panci, Wajan, Loyang, Sedok dan Kompor. Sementara bahan - bahan yang dipakai meliputi N-Heksana, Aceton, Magnesium carbosat, Silicagel kolom kromatografi, 
Vitamin A standar, Natrium sulfat dan Daun paku-paku muda.

Tahapan penelitian dilakukan mulai dari penyiapan alat dan bahan, preparasi sampel, pemasakan daun paku-paku (Tumis, Kukus dan Rebus) dan analisis kandungan vitamin $A$.

\section{Penyiapan Alat dan Bahan}

Semua alat dan bahan disiapkan, kemudian di bersihkan (alat-alat yang terbuat dari kaca/gelas juga bersihkan dan disterilkan.

\section{Preparasi Sampel (Daun paku-paku)}

Daun paku-paku muda di ambil lalu di bersikan dan Daun dipetik dari tangkainya . lalu melakukan proses pemasakan (tumis, Kukus dan Rebus) menggunakan waktu 5 menit, 10 menit dan 15 menit.

\section{Analisis Kandungan Vitamin A dengan Spektofotometer (Parwata dkk., 2010)}

1. Timbang sebanyak 4 gram sampel yang telah diolah, dimasukan kedalam erlenmeyer 1 gram magnesium carbonat dan $100 \mathrm{ml}$ larutan Aceton : $\mathrm{n}$ hexana $(40: 60)$.

2. Larutan diaduk selama $15-20$ menit agar semua vitamin A larut dalam larutan secara sempurna.

3. Lakukan penyaringan dengan penyaringan vacum, bilas kertas saring dengan $15 \mathrm{ml}$ larutan $\mathrm{n}$-hexana, kemudian bilas dengan $15 \mathrm{ml}$ aceton.

4. Pindahkan hasil penyaringan ke dalam corong pisah dan lakukan pemisahan untuk memisahkan lapisan polar dan non polar.

5. Masukan lapisan air (polar) kedalam corong pisah lakukan ekstrasi dengan $15 \mathrm{ml}$ larutan $\mathrm{n}$-hexana, dan gabungkan lapisan n-hexana dengan hasil pemisahan pertama.
6. Lapisan n-hexana dimasukan kedalam corong pisah, kemudian dicuci dengan $50 \mathrm{ml}$ aquades.

7. Hasil pemisahan (lapisan n-hexana) dimasukan kedalam labu epavorasi dan dilakukan epavorasi pada suhu $30^{\circ} \mathrm{C}$ sampai bebas pelarut $n$-hexana.

8. Siapkan kolom kromatografi dengan fase diam aluminium oksida yang telah diaktifasikan pada suhu $100^{\circ} \mathrm{C}$ selama 3-4 jam dan fase gerak terdiri dari $n$ hexana : aceton $(9: 1)$.

9. Campurkan fase gerak dengan fase diam untuk menghilangkan udara yang ada didalam fase diam dan tempatkan corong pada ujung kolom kromatografi. Kolom komatografi untuk memisahkan vitamin $A$ dari komponen lain yang larut dalam $n$ - hexana : Aceton $(9: 1)$.

10. Spektofotometer untuk mengukur nilai absorbansi standar vitamin A dan absorbansi sampel.

\section{Teknik Analisis Data}

Analisis data yang digunakan dalam penelitian ini adalah analisis statistik inferensial menggunakan two way anova untuk menganalisis pengaruh proses pemasakan pada daun paku-paku muda. Sebelum dilakukan uji two way anova, dilakukan uji prasyarat normalitas data menggunakan uji Shapiro-Wilk dan uji Homeginetas data menggunakan uji Levene's test apabila analisis one away anova menunjukan hasil yang signifikan maka dilanjutkan uji post LSD analisis inferensial ini menggunakan fasilitas program SPSS windows 17 untuk tingkat kepercayaan $5 \%$.

\section{HASIL DAN PEMBAHASAN}

Hasil analisis kandungan vitamin A berdasarkan proses pemasakan dapat dilihat pada table berikut.

Tabel 1. Hasil Analisis Kandungan Vitamin A Berdasarkan Proses Pemasakan

\begin{tabular}{llllcccc}
\hline No & Perlakuan & Waktu & $\begin{array}{c}\text { Kode } \\
\text { Sampel }\end{array}$ & $\begin{array}{c}\text { Berat } \\
\text { Sampel }\end{array}$ & Absorban & $\begin{array}{c}\text { Konsentrasi } \\
\text { vitamin A }\end{array}$ & $\begin{array}{c}\text { Kadar } \\
\text { vitamin A }\end{array}$ \\
\hline 1 & Tumis & 5 & $\mathrm{U} 1$ & 4,0676 & 0,344 & 2,25 & 0,0553 \\
\cline { 3 - 7 } & menit & $\mathrm{U} 2$ & 4,0713 & 0,349 & 2,30 & 0,0564 \\
\cline { 3 - 7 } & 10 & $\mathrm{U} 1$ & 4,0341 & 0,365 & 2,40 & 0,0594 \\
\cline { 3 - 7 } & menit & $\mathrm{U} 2$ & 4,0331 & 0,358 & 2,35 & 0,0582 \\
\cline { 3 - 7 } & 15 & $\mathrm{U} 1$ & 4,0892 & 0,338 & 2,20 & 0,0538 \\
\hline
\end{tabular}




\begin{tabular}{|c|c|c|c|c|c|c|c|}
\hline & & menit & U2 & 4,0689 & 0,342 & 2,25 & 0,0552 \\
\hline \multirow[t]{6}{*}{2} & \multirow[t]{6}{*}{ Kukus } & \multirow{2}{*}{$\begin{array}{l}5 \\
\text { menit }\end{array}$} & U1 & 4,0774 & 0,251 & 1,65 & 0,0404 \\
\hline & & & U2 & 4,0987 & 0,249 & 1,65 & 0,0402 \\
\hline & & \multirow{2}{*}{$\begin{array}{l}10 \\
\text { menit }\end{array}$} & U1 & 4,1812 & 0,265 & 1,75 & 0,0418 \\
\hline & & & $\mathrm{U} 2$ & 4,0973 & 0,270 & 1,80 & 0,0439 \\
\hline & & \multirow{2}{*}{$\begin{array}{l}15 \\
\text { menit }\end{array}$} & U1 & 4,0760 & 0,269 & 1,75 & 0,0429 \\
\hline & & & U2 & 4,0688 & 0,273 & 1,80 & 0,0442 \\
\hline \multirow[t]{6}{*}{3} & \multirow[t]{6}{*}{ Rebus } & \multirow{2}{*}{$\begin{array}{l}5 \\
\text { menit }\end{array}$} & U1 & 4,1104 & 0,159 & 1,05 & 0,0255 \\
\hline & & & $\mathrm{U} 2$ & 4,1083 & 0,155 & 1,00 & 0,0243 \\
\hline & & \multirow{2}{*}{$\begin{array}{l}10 \\
\text { menit }\end{array}$} & U1 & 4,0991 & 0,149 & 0,95 & 0,0231 \\
\hline & & & U2 & 4,1071 & 0,145 & 0,95 & 0,0231 \\
\hline & & \multirow{2}{*}{$\begin{array}{l}15 \\
\text { menit }\end{array}$} & U1 & 4,1253 & 0,146 & 0,95 & 0,0230 \\
\hline & & & U2 & 4,1472 & 0,140 & 0,90 & 0,0217 \\
\hline
\end{tabular}

Keterangan:

U1: Pengulangan pertama

U2 : Pengulangan kedua

Data pada tabel 1 di atas dilakukan menggunakan uji two way anova, sebelum dilakukan uji two way anova dilakukan uji prasyarat yang meliputi uji normalitas dan uji homogenitas. Hasil uji normalitas dan uji homogenitas ditunjukan pada tabel 2 dan tabel 3.

\section{Tabel 2. Ringkasan Uji Normalitas.}

\begin{tabular}{lllllll}
\hline \multicolumn{7}{c}{ Tests of Normality } \\
\hline \multicolumn{7}{l}{ Kolmogorov-Smirnov } \\
\hline & Statistic & Df & Sig. & Statistic & df & Sig. \\
\hline Data & .195 & 18 & .069 & .869 & 18 & .017 \\
\hline
\end{tabular}

Hasil analisis normalitas data menggunakan uji One Sample Kolmogorov Smirnov, maka diperoleh $p$ value 0,069 $(p=0,069>\alpha=0,05)$, sehingga dapat disimpulkan bahwa data berdistribusi normal.

Tabel 3. Ringkasan Uji Homogenitas.

\begin{tabular}{|c|c|c|c|c|c|}
\hline \multicolumn{6}{|c|}{ Test of Homogeneity of Variance } \\
\hline & & Lever & df1 & $\mathrm{df2}$ & Sig. \\
\hline \multirow[t]{4}{*}{ Data } & Based on Mean & .899 & 2 & 15 & .428 \\
\hline & Based on Median & .959 & 2 & 15 & .405 \\
\hline & $\begin{array}{l}\text { Based on Media } \\
\text { and with adjusted } 0\end{array}$ & .959 & 2 & 12.753 & .409 \\
\hline & $\begin{array}{l}\text { Based on trimme } \\
\text { mean }\end{array}$ & .910 & 2 & 15 & .424 \\
\hline
\end{tabular}

Hasil homogenitas data di uji menggunakan Levene's Test, maka diperoleh seluruh kriteria dengan nilai $p$ value seluruhnya di atas 0.05 ( $p$ value $>\alpha=0,05)$, sehingga dapat disimpulkan bahwa data homogen. Oleh karena, data hasil penelitian telah memenuhi persyaratan normalitas dan homogenitas data, maka dilajutkan untuk analisis varians ganda. 
Tabel 4. Analisis Pengukuran Vitamin A Berdasarkan Jenis Pemasakan Dan Waktu Pemasakan Pada Daun Paku-Paku (Diplazium escelentum Retz.) Sw.).

\begin{tabular}{llllll}
\hline Sumber keragaman & $\begin{array}{c}\text { Jumlah } \\
\text { kuadrat }\end{array}$ & Df & $\begin{array}{c}\text { Rata-rata } \\
\text { kuadrat }\end{array}$ & F & Sig. \\
\hline Model & $.003^{\mathrm{a}}$ & 8 & .000 & 537.082 & .000 \\
\hline Intercept & .030 & 1 & .030 & $3.865 \mathrm{E} 4$ & .000 \\
\hline Jenis_pemasakan & .003 & 2 & .002 & $2.124 \mathrm{E} 3$ & .000 \\
\hline $\begin{array}{l}\text { Waktu_pemasakan } \\
7.341 \mathrm{E}-6\end{array}$ & 2 & $3.671 \mathrm{E}-6$ & 4.760 & .039 \\
\hline $\begin{array}{l}\text { Jenis_pemasakan } \\
\text { waktu_pemasakan }\end{array}$ & $3.058 \mathrm{E}-5$ & 4 & $7.644 \mathrm{E}-6$ & 9.913 & .002 \\
\hline Galat & $6.940 \mathrm{E}-6$ & 9 & $7.711 \mathrm{E}-7$ & & \\
\hline Total & .033 & 18 & & & \\
\hline
\end{tabular}

Hasil analisis varians pada tabel 4 di atas menunjukkan bahwa nilai $F_{\text {hit }}$ variabel pemasakan ialah sebesar 2.124 dengan tingkat signifikansi $0,000 \quad(p=0,000<\alpha=$ $0,05)$, sehingga hipotesis penelitian I diterima, artinya terdapat pengaruh jenis pemasakan terhadap kadar vitamin A diterima. Sedangkan Fhit variabel waktu pemasakan ialah sebesar 4.760 dengan tingkat signifikansi $0,039 \quad(p=0,039<\alpha=$ $0,05)$, sehingga hipotesis penelitian II diterima, artinya terdapat pengaruh waktu pemasakan terhadap kadar vitamin $\mathrm{A}$. Adapun Fhit interaksi jenis pemasakan dengan waktu pemasakan ialah sebesar 9,913 dengan tingkat signifikansi sebesar $0,002 \quad(p=0,002<\alpha=0,05)$, sehingga hipotesis III diterima, artinya ada interaksi antara jenis pemasakan dengan waktu pemasakan terhadap kadar vitamin A.

Selanjutnya dilakukan uji LSD (Least Significance difference) dengan taraf kepercayaan $5 \%$ untuk menentukan perbedaan rata-rata kadar vitamin A dari setiap jenis pemasakan, waktu pemasakan dan interaksi antara jenis pemasakan dan waktu pemasakan. Hasil uji LSD ditunjukkan pada Tabel 4.5. di bawah ini.

Tabel 5. Hasil Uji LSD Variasi Jenis Pemasakan terhadap Kadar Vitamin A.

\begin{tabular}{lcc}
\hline Jenis Pemasakan & Rerata & Notasi \\
\hline Rebus & .023450 & $\mathrm{~A}$ \\
Kukus & .042233 & $\mathrm{~B}$ \\
Tumis & .056383 & $\mathrm{C}$ \\
\hline
\end{tabular}

Berdasarkan tabel 5 di atas diketahui bahwa adanya perbedaan notasi menunjukkan perbedaan yang sangat nyata pada masing-masing jenis pemasakan.
Jenis pemasakan tumis memiliki kadar vitamin A yang lebih tinggi apabila dibandingkan pemasakan kukus dan rebus.

Tabel 6. Hasil Uji LSD Variasi Waktu Pemasakan terhadap Kadar Vitamin A.

\begin{tabular}{llc}
\hline \multicolumn{1}{c}{ Jenis Pemasakan } & \multicolumn{1}{c}{ Rerata } & Notasi \\
\hline 15 menit & .040133 & $\mathrm{~A}$ \\
5 menit & .040350 & $\mathrm{~A}$ \\
10 menit & .041583 & $\mathrm{~B}$ \\
\hline
\end{tabular}

Berdasarkan tabel 6 di atas diketahui bahwa adanya perbedaan notasi menunjukkan perbedaan yang sangat nyata pada masing-masing waktu pemasakan.
Waktu pemasakan 10 menit memiliki kadar vitamin $A$ yang lebih tinggi apabila dibandingkan waktu pemasakan 5 dan 15 menit. 


\section{Tabel 7. Hasil Uji LSD Interaksi Jenis Pemasakan dengan Waktu Pemasakan terhadap} Kadar Vitamin A Sayur Paku-Pakuan.

\begin{tabular}{lccc}
\hline \multicolumn{1}{c}{ Jenis Pemasakan } & \multicolumn{1}{c}{ Rerata } & \multicolumn{2}{c}{ Notasi } \\
\hline rebus 15 menit & .022350 & $\mathrm{a}$ & \\
rebus 10 menit & .023100 & $\mathrm{a} \mathrm{b}$ & \\
rebus 5 menit & .024900 & $\mathrm{~b}$ & \\
kukus 5 menit & .040300 & \multicolumn{2}{c}{$\mathrm{C}$} \\
kukus 10 menit & .042850 & \multicolumn{2}{c}{$\mathrm{d}$} \\
kukus 15 menit & .043550 & \multicolumn{2}{c}{$\mathrm{d}$} \\
tumis 15 menit & .054500 & \multicolumn{2}{c}{$\mathrm{f}$} \\
tumis 5 menit & .055850 & & $\mathrm{f}$ \\
tumis 10 menit & .058800 & & $\mathrm{~g}$ \\
\hline
\end{tabular}

Berdasarkan tabel 7 di atas diketahui bahwa interaksi rebus 10 menit memiliki kadar vitamin A yang tidak berbeda nyata dengan rebus 5 menit atau rebus 15 menit, karena memiliki notasi yang sama, namun berbeda nyata dengan interkasi kukus 5 menit, 10 menit dan 15 menit, serta tumis 15, 5 dan 10 menit, karena menunjukkan notasi yang berbeda. Interaksi kukus 5 menit juga berbeda nyata dengan kukus 10 menit dan 15 menit, namun interaksi kukus 10 menit tidak berbeda nyata dengan kukus 15 menit. Interaksi tumis 15 menit dan tumis 5 menit tidak berbeda nyata namun berbeda nyata dengan tumis 10 menit. Secara keseluruhan, tumis 10 menit memiliki kadar vitmin A yang lebih tinggi dibandingkan dengan interaksi yang lain. Waktu pemasakan 10 menit memiliki kadar vitamin A yang lebih tinggi apabila dibandingkan waktu pemasakan 5 dan 10 menit.

Analisis Kandungan Vitamin A Pada
Daun Paku-paku (diplazium escelentum
(Retz.) Sw.) Berdasarkan Proses
Pemasakan
Berdasarkan hasil penelitian
menunjukan bahwa adanya pengaruh
pemasakan terhadap kandungan vitamin A
pada daun paku-paku (Diplazium
escelentum Retz.) Sw.) berdasarkan proses
pemasakan yang dilakukan yaitu
penumisan, perebusan dan pengukusan.
Kandungan vitamin A yang tertinggi
terdapat pada proses pemasakan dengan
ditumis. Pada uji LSD menunjukan bahwa
adanya perbedaan notasi pada masing-
masing jenis pemasakan, dan terlihat
bahwa jenis pemasakan penumisan

memiliki kadar yang lebih tinggi dari jenis pemasakan perebusan dan pengukusan. karena vitamin A yang dicampurkan dalam minyak, mudah rusak oleh karena udara, cahaya dan panas. Tetapi penelitian di banyak negara dan Indonesia, menunjukkan bahwa vitamin A dalam MGS cukup stabil, tidak mudah rusak seperti anggapan banyak orang selama ini. Vitamin A dalam minyak lebih peka terhadap cahaya dibandingkan terhadap panas. Marliyati 2017.

Vitamin A dalam minyak goreng yang dipanaskan dalam proses penggorengan yang wajar, ternyata juga tidak rusak atau hilang. Penelitian mahasiswi IPB menunjukkan bahwa MGS fortifikasi sesudah digunakan untuk menggoreng tiga kali vitamin A nya masih tersisa lebih dari $50 \%$. Jika di gunakan untuk menumis lebih banyak vitamin A masih bertahan karena durasi pemanasan yang lebih singkat. Marliyati 2017. Penurunan kadar gizi bahan pangan akibat pengolahan panas bergantung pada beratnya proses pengelolahan (Adelina, 2013). Jadi pemasakan pada sayuran terutama sayuran paku-paku jangan terlalu lama karena merusak kandungan vitamin dan meniral yang terkandung didalamnya terutama kandungan vitamin A pada sayur paku-paku diplazium escelentum.

Hasil penelitian menunjukan bahwa semua metode pemasakan mengarah ke rilis yang signifikan dari semua trans-bkariten dan cis-isomernya. Dalam sayur paku-paku betakaroten tergabung dalam karatonoid-protein kompleks dalam kloroplas yang disebut carotenoproteins dan memiliki efek penghambat pada 
extractability dari $\beta$-karoten. Dari matriks sayuran. Pemasakan menyebabkan pelunakan jaringan tanaman dan denaturasi protein sehingga karotenoid dapat diekstrak jauh lebih mudah. Hal ini sering diasumsikan bahwa dengan meningkatnya daya terekstraksinya berhubungan dengan peningkatan bioavailabilitas beta karoten ( Tezar 2014).

Sebuah studi terbaru yang dilakukan oleh Mazzeo et. al. (2011) Menunjukan pengaruh perebusan, penumisan dan pengukusan terhadap kandungan total karotenoid wortel dan bayam Setelah perebusan, total kandungan karotenoid wortel dan bayam berkurang signifikan. Pengurangan tersebut kemungkinan terkait dengan pelepasan karoten ke dalam air mendidih. Sebaliknya, pengukusan adalah prosedur memasak terbaik untuk menjaga total karoten pada bayam ( Tezar 2014).

Sayuran yang ditumis mempunyai kadar air relatif rendah daripada sayuran yang direbus atau dikukus. Hal ini karena matrik jaringan sayuran yang semula terisi oleh air serta komponen organik lainnya akan terdegradasi, kemudian keluar dari jaringan dan digantikan oleh misel-misel minyak. Menurut Ketaren (1986), jika bahan segar ditumis, maka kulit bagian luar akan mengerut akibat proses dehidrasi. Pengerutan terjadi akibat panas dari minyak menguapkan air yang terdapat pada bahan makanan. Selama proses menumis berlangsung, sebagian minyak akan masuk ke dalam bahan kemudian mengisi ruang kosong yang semula diisi air dan komponen organik lainnya.

\section{KESIMPULAN}

Berdasarkan hasil penelitian, kandungan vitamin A pada sayur paku-paku (Diplazium escelentum (Retz.) Sw.)) tertinggi terdapat pada proses pemasakan jenis penumisan dengan kandungan vitamin A sebesar 0,0594 dengan lama waktu 10 menit.

\section{DAFTAR PUSTAKA}

Adelina, $R$ 2013. Perebusan dan penumisan menurunkan kandungan beta karoten dalam wortel.
Azrimaidaliza, 2007. Vitamin A, Imunitas Dan Kaitannya Dengan Penyakit Infeksi. Jurnal Kesehatan Masyarakat, September 2007, I (2).

Fleming, Sarah. 2009. Phyla Pterophyta and Lycophyta: Ferns and Their Relatives.

Karmilasanti, Supartini, 2011. Keragaman Jenis Tumbuhan Obat dan Pemanfaatannya di Kawasan Tane' Olen Desa Setulang Malinau, Kalimantan Timur. Jurnal Penelitian Dipterokarpa. 5(1): 23- 38.

Lense, Obed. 2012. The wild Plant Used as Traditional medicine by indigenous people of Manukwari, West Papua. Biodiversitas. 13 (2): 98- 106.

Marliyati .2017. Pengaruh Pengeringan Terhadap Kadar Senyawa Antinutrisi yang Mempengaruhi Ketersediaan Zat Besi Serta Fortifikasi Zat Besi Pada Rempah-Rempah. (Tesis). Program Pascasarjana. Institut Pertanian Bogor.

Mazzeo et. al. 2011. Ilmu Gizi Untuk Mahasiswa dan Profesi. Jilid 1. Jakarta: Dian Rakyat.

Parwata, I. M. Oka Adi, dkk. 2010. Aktivitas Antiradikal Bebas Serta Kadar Beta Karoten Pada Madu Randu (Ceiba pentandra) Dan Madu Kelengkeng (Nephelium longata L.): Jurnal Kimia 4 (1), Januari 2010: 54-62. Bukit Jimbaran: Jurusan Kimia FMIPA Universitas Udayana.

Ketaren, 1986. Minyak dan Lemak Pangan. Universitas Indonesia Press, Jakarta.

Setyowati, S. 2005. Pengaruh Berat Awal Yang Berbeda Terhadap Laju Pertumbuhan Gracillaria verrucosa di Pertambakan Kalirejo, Kendal [skripsi] Universitas Diponegoro. Semarang. (Tidak Dipublikasikan).

Tjitrosoepomo, G. 1991. Taksonomi Tumbuhan. Gadjah Mada University Press.

Tjitrosoepomo,G. 1983. Taksonomi Tumbuhan (Schizophtya, Thallophyta, Bryophyta, Pteridophyta). Cet. Ke 7. Gadja Mada University Press, Yogyakarta. P.219-307.

Tezar 2014. Kandungan Nutrien dan Ketersediaan Besi dan Seng Hayati Sargassum sp. Diukur secara In Vitro. [Laporan Penelitian]. Yogyakarta: Fakultas Biologi UGM. 